Article

\title{
Lignan Glucosides from the Stem Barks of Illicium difengpi
}

\author{
Zheng-Hong Pan ${ }^{1, *,+}$, De-Sheng Ning ${ }^{1,+}{ }^{\dagger}$, Si-Si Huang ${ }^{1}$, Ling Cheng ${ }^{1,2}$, Meng-Wen Xia ${ }^{1,2}$, \\ Li-Yan Peng ${ }^{3}$ and Dian-Peng $\mathrm{Li}^{1, *}$ \\ 1 Guangxi Key Laboratory of Functional Phytochemicals Research and Utilization, \\ Guangxi Institute of Botany, Chinese Academy of Sciences, Guilin 541006, China; \\ ndshgxib@sina.com (D.-S.N.); ssh520123@163.com (S.-S.H.); 15507837860@163.com (L.C.); \\ xmw1036978486@126.com (M.-W.X.) \\ 2 Faculty of Chemistry and Chemical Engineering, Yunnan Normal University, Kunming 650500, China \\ 3 State Key Laboratory of Phytochemistry and Plant Resources in West China, Kunming Institute of Botany, \\ Chinese Academy of Sciences, Kunming 650204, China; pengliyan@mail.kib.ac.cn \\ * Correspondence: pan7260@126.com (Z.-H.P.); ldp@gxib.cn (D.-P.L.); \\ Tel.: +86-773-355-0194 (Z.-H.P. \& D.-P.L.); Fax: +86-773-355-0067 (Z.-H.P.) \\ + These authors contributed equally to this work.
}

Academic Editor: Derek J. McPhee

Received: 6 April 2016; Accepted: 4 May 2016; Published: 10 May 2016

\begin{abstract}
In this study, four new lignan glucosides, named difengpiosides A-D (1-4), were isolated from the stem barks of Illicium difengpi, together with seven known compounds 5-11. Their structures were identified on the basis of spectroscopic analyses (1D and 2D NMR, HRESIMS, CD) and a comparison with literature data. All the compounds were evaluated for their inhibitory effects on lipopolysaccharide (LPS)-induced nitric oxide (NO) production in RAW264.7 cells.
\end{abstract}

Keywords: Illicium difengpi; stem barks; lignan glucosides; difengpiosides A-D; NO inhibition

\section{Introduction}

Illicium difengpi K. I. B et K. I. M. (Illiciaceae), native to China, is a toxic shrub that grows in the mountainous areas of Guangxi Province. Its stem bark is listed in the Chinese Pharmacopeia as a traditional Chinese medicine to treat rheumatic arthritis [1]. Previous phytochemical studies on this plant mainly focused on the low and middle polarity components and reported the isolation of over 40 compounds, including phenylpropanoids, lignans, triterpene acids, sesquiterpenes and others [2-7]. However, there are few investigations on the polar substances of I. difengpi. In order to provide comprehensive chemistry support for pharmacological studies and quality control of I. difengpi, the present study describes the isolation and structure elucidation of four new lignan glycosides together with seven known compounds from the $n$ - $\mathrm{BuOH}$-soluble fraction of an $\mathrm{EtOH}$ extract of the stem barks of this plant, as well as their inhibitory activities against nitric oxide production in lipopolysaccharide-induced RAW264.7 cells.

\section{Results and Discussion}

The EtOH extract of the stem barks of I. difengpi were suspended in water and successively partitioned with petroleum ether, EtOAc, and $n$ - $\mathrm{BuOH}$. The $n$ - $\mathrm{BuOH}$-soluble extract was subjected to multiple chromatographic fractionations using silica gel, Sephadex LH-20, and ODS, yielding compounds 1-11 (Figure 1). 

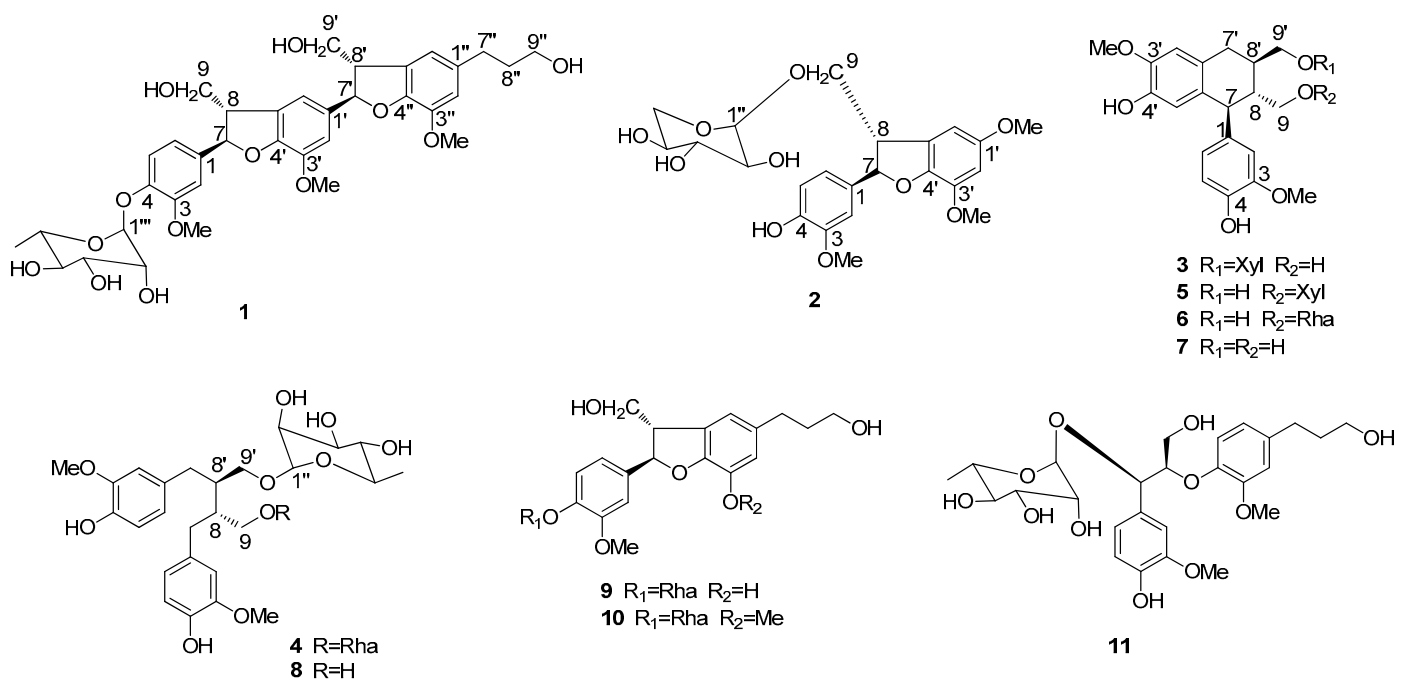

Figure 1. Chemical structures of 1-11.

Compound 1 was obtained as an amorphous powder. The molecular formula was determined as $\mathrm{C}_{36} \mathrm{H}_{44} \mathrm{O}_{13}$ on the basis of a HRESIMS peak at $m / z 707.2623[\mathrm{M}+\mathrm{Na}]^{+}$(calcd. for 707.2674), indicating 15 degrees of unsaturation. The IR spectrum showed the presence of hydroxyl $\left(3406 \mathrm{~cm}^{-1}\right)$ and aromatic ring (1595 and $1501 \mathrm{~cm}^{-1}$ ) groups. The ${ }^{1} \mathrm{H}-\mathrm{NMR}$ spectrum (Table 1) displayed signals at $\delta_{\mathrm{H}}$ $7.07(1 \mathrm{H}, \mathrm{d}, J=8.5 \mathrm{~Hz}), 7.01(1 \mathrm{H}, \mathrm{d}, J=2.0 \mathrm{~Hz})$ and $6.89(1 \mathrm{H}, \mathrm{dd}, J=8.5,2.0 \mathrm{~Hz})$ for an AMX aromatic spin system, and four broad singlets at $\delta_{\mathrm{H}} 6.92(2 \mathrm{H})$ and $6.72(2 \mathrm{H})$ for two tetrasubstituted aromatic rings, as well as three aromatic methoxy groups at $\delta_{\mathrm{H}} 3.85(6 \mathrm{H}, \mathrm{s})$ and $3.80(3 \mathrm{H}, \mathrm{s})$. The remaining signals indicated the presence of a sugar moiety, an $n$-propanol and two $-\mathrm{O}-\mathrm{CH}-\mathrm{CH}-\mathrm{CH}_{2} \mathrm{O}-$ spin systems, which were also confirmed by the ${ }^{1} \mathrm{H}^{1}{ }^{1} \mathrm{H}$ COSY spectrum (Figure 2). The ${ }^{13} \mathrm{C}-\mathrm{NMR}$ spectrum (Table 1$)$ showed the presence of six characteristic rhamnopyranoside signals $\left(\delta_{\mathrm{C}} 101.5,73.9,72.3,72.1\right.$, 70.9, and 18.0) and another 30 carbons, including eighteen aromatic carbon signals of three benzene rings, two oxygenated methine carbons at $\delta_{\mathrm{C}} 89.2$ and 88.8, three methyleneoxy carbons at $\delta_{\mathrm{C}} 65.1$, 64.9 and 62.3 , three methoxy carbons at $\delta_{\mathrm{C}} 56.9,56.8$ and 56.5 , two methine carbons at $\delta_{\mathrm{C}} 55.5$ and 55.5 , two methylene carbons at 35.8 and 32.9.
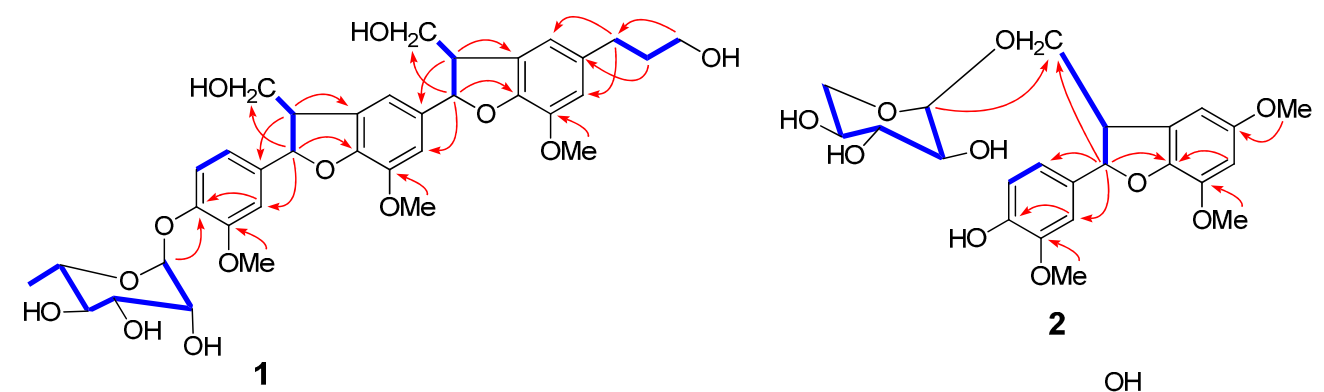

2

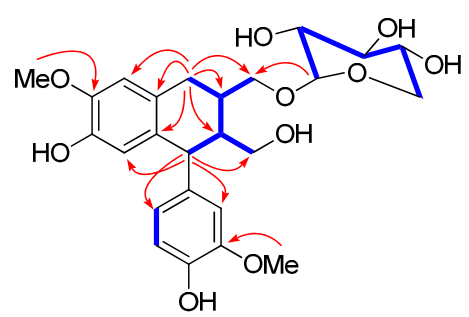

3

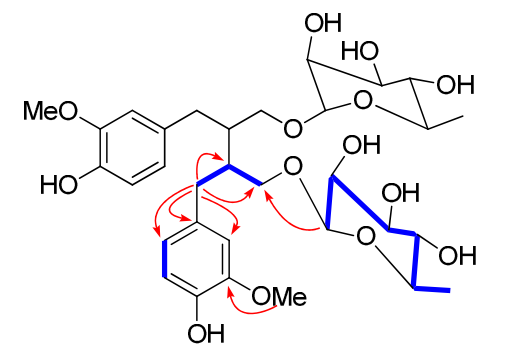

4

Figure 2. Key ${ }^{1} \mathrm{H}_{-}{ }^{1} \mathrm{H}$ COSY and $\mathrm{HMBC}$ correlations of compounds 1-4. 
Table 1. NMR data of compound 1 (in $\mathrm{CD}_{3} \mathrm{OD}, \mathrm{J}$ in $\mathrm{Hz}$ ).

\begin{tabular}{cccccc}
\hline No. & $\delta_{\mathbf{C}}$ & $\delta_{\mathbf{H}}$ & No. & $\delta_{\mathbf{C}}$ & $\delta_{\mathbf{H}}$ \\
\hline 1 & 138.6 & & $1^{\prime \prime}$ & 137.1 & \\
2 & 111.4 & $7.01 \mathrm{~d}(2.0)$ & $2^{\prime \prime}$ & 112.0 & $6.72 \mathrm{~s}$ \\
3 & 152.2 & & $3^{\prime \prime}$ & 145.3 & \\
4 & 146.7 & & $4^{\prime \prime}$ & 147.5 & \\
5 & 119.7 & $7.07 \mathrm{~d}(8.5)$ & $5^{\prime \prime}$ & 129.9 & \\
6 & 119.2 & $6.89 \mathrm{dd}(8.5,2.0)$ & $6^{\prime \prime}$ & 117.9 & $6.72 \mathrm{~s}$ \\
7 & 88.8 & $5.58 \mathrm{~d}(6.0)$ & $7^{\prime \prime}$ & 32.9 & $2.61 \mathrm{t}(7.5)$ \\
8 & 55.5 & $3.49 \mathrm{~m}$ & $8^{\prime \prime}$ & 35.8 & $1.80 \mathrm{~m}$ \\
9 & 65.1 & $3.83 \mathrm{~m}$ & $9^{\prime \prime}$ & 62.3 & $3.55 \mathrm{t}(6.5)$ \\
$1^{\prime}$ & 137.0 & & $1^{\prime \prime \prime}$ & 101.5 & $5.33 \mathrm{~d}(1.5)$ \\
$2^{\prime}$ & 112.0 & $6.92 \mathrm{~s}$ & $2^{\prime \prime \prime}$ & 72.1 & $4.04 \mathrm{dd}(3.5,2.0)$ \\
$3^{\prime}$ & 145.6 & & $3^{\prime \prime \prime}$ & 72.3 & $3.86 \mathrm{~m}$ \\
$4^{\prime}$ & 149.3 & & $4^{\prime \prime \prime}$ & 73.9 & $3.43 \mathrm{t}(9.5)$ \\
$5^{\prime}$ & 130.1 & & $5^{\prime \prime \prime}$ & 70.9 & $3.78 \mathrm{~m}$ \\
$6^{\prime}$ & 115.8 & $6.92 \mathrm{~s}$ & $6^{\prime \prime \prime}$ & 18.0 & $1.20 \mathrm{~d}(6.0)$ \\
$7^{\prime}$ & 89.2 & $5.52 \mathrm{~d}(6.5)$ & $3-\mathrm{MeO}$ & 56.5 & $3.80 \mathrm{~s}$ \\
$8^{\prime}$ & 55.5 & $3.49 \mathrm{~m}$ & $3^{\prime}-\mathrm{MeO}$ & 56.8 & $3.85 \mathrm{~s}$ \\
$9^{\prime}$ & 64.9 & $3.75 \mathrm{~m}$ & $3^{\prime \prime}-\mathrm{MeO}$ & 56.9 & $3.85 \mathrm{~s}$ \\
\hline
\end{tabular}

These spectral features implied that the aglycone of 1 should be a dimer of dihydrobenzofuran neolignan and was the same as vitrifol A [8]. The rhamnose unit was located at C-4 as elucidated by the HMBC correlation between $\delta_{\mathrm{H}} 5.33\left(\mathrm{H}-1^{\prime \prime \prime}\right)$ and $\delta_{\mathrm{C}} 146.7(\mathrm{C}-4)$ (Figure 2). The $\alpha$-orientation of the sugar was determined by the small coupling constant $(J=1.5 \mathrm{~Hz})$ of the anomeric proton $\mathrm{H}-1^{\prime \prime \prime}$ and its L-configuration was established by HPLC analysis after acid hydrolysis. By comparison with reported data [9], the relative configuration of $\mathrm{H}-7 / \mathrm{H}-8$ and $\mathrm{H}-7^{\prime} / \mathrm{H}-8^{\prime}$ was determined as threo according to their coupling constants $\left(J_{7,8}=6.0 \mathrm{~Hz}\right.$ and $\left.J_{7^{\prime}, 8^{\prime}}=6.5 \mathrm{~Hz}\right)$. The absolute configuration of 1 was established as $7 R, 8 S$ and $7^{\prime \prime} R, 8^{\prime \prime} S$ on the basis of the negative Cotton effects at 237 and 290 $\mathrm{nm}$ in the circular dichroism (CD) spectrum as shown in Figure S8, Supplementary Materials [10]. From the above analysis, compound 1 was determined to be vitrifol A 4- $\alpha$-L-rhamnopyranoside, and named as difengpioside A. To the best of our knowledge, this is the first report of a dihydrobenzofuran sesquilignan glucoside from the family Illiciaceae.

Compound 2 was isolated as an amorphous powder. The HRESIMS spectrum showed a peak at $m / z 487.1572[\mathrm{M}+\mathrm{Na}]^{+}$(calcd. for 487.1575), corresponding to the molecular formula $\mathrm{C}_{23} \mathrm{H}_{28} \mathrm{O}_{10}$. The IR spectrum displayed the presence of hydroxyl $\left(3412 \mathrm{~cm}^{-1}\right)$ and aromatic ring (1595 and 1501 $\mathrm{cm}^{-1}$ ) groups. The ${ }^{1} \mathrm{H}-\mathrm{NMR}$ spectrum (Table 2) displayed AMX aromatic spin-system signals at $\delta_{\mathrm{H}} 6.76(1 \mathrm{H}, \mathrm{d}, J=8.0 \mathrm{~Hz}), 6.83(1 \mathrm{H}, \mathrm{dd}, J=8.0,1.5 \mathrm{~Hz})$ and $6.97(1 \mathrm{H}, \mathrm{d}, J=1.5 \mathrm{~Hz})$, two aromatic $\mathrm{H}$-atom signals at $\delta_{\mathrm{H}} 7.02(1 \mathrm{H}, \mathrm{s})$ and $6.56(1 \mathrm{H}, \mathrm{s})$, three aromatic methoxy groups at $\delta_{\mathrm{H}} 3.83(3 \mathrm{H}, \mathrm{s}), 3.82(3 \mathrm{H}, \mathrm{s})$ and $3.79(3 \mathrm{H}, \mathrm{s})$, and an anomeric proton of xylose at $\delta_{\mathrm{H}} 4.31(1 \mathrm{H}, \mathrm{d}$, $J=7.5 \mathrm{~Hz}$ ) which indicated a $\beta$-configurantion for the xylosyl moiety. The ${ }^{13} \mathrm{C}-\mathrm{NMR}$ spectrum (Table 2) showed the presence of 23 carbons including twelve aromatic carbon signals of two benzene rings, an oxygenated methine carbon at $\delta_{\mathrm{C}} 89.0$, a methyleneoxy carbon at $\delta_{\mathrm{C}} 72.8$, three methoxy carbons at $\delta_{\mathrm{C}} 57.8,56.6$ and 56.4, and a methine carbon at $\delta_{\mathrm{C}} 52.7$. Additionally, five carbon signals $\left(\delta_{C} 105.0,77.9,74.9,71.2\right.$, and 66.9$)$ were ascribed to a xylosyl moiety. The NMR data were quite identical to those of the known compound 2,3-dihydro-7-methoxy-2-(4'-hydroxy-3'-methoxyphenyl)-3a-O- $\beta$-D-xylopyranosyloxymethyl-5-benzofuranpropanol [5]. The only difference lies in that the propanol moiety at $\mathrm{C}-1^{\prime}$ of the known compound was replaced by a methoxyl group in 2 , as confirmed by the HBMC correlation from $\delta_{\mathrm{H}} 3.82\left(\mathrm{OCH}_{3}\right)$ to $\delta_{\mathrm{C}} 151.6\left(\mathrm{C}-1^{\prime}\right)$ (Figure 2) and the molecular formula of 2 . The xylose unit was located at C-9 as elucidated by the HMBC correlation between $\delta_{\mathrm{H}} 4.31\left(\mathrm{H}-\mathrm{-}^{\prime \prime}\right)$ and $\delta_{\mathrm{C}} 72.8(\mathrm{C}-9)$ and its D-configuration was detected by direct comparison with an authentic sample on HPLC after acid hydrolysis. The absolute configurations of C-7 and 
C-8 of 2 were determined as $7 R, 8 S$, on the basis of their coupling constant $\left(J_{7,8}=6.5 \mathrm{~Hz}\right)$, indicating $\mathrm{H}-7$ and $\mathrm{H}-8$ to be threo, and the negative Cotton effects at 243 and $287 \mathrm{~nm}$ in the CD spectrum [10]. Compound 2 was thus identified as (2R,3S)-2,3-dihydro-5,7-dimethoxy-2-(4'-hydroxy-3'-methoxyphenyl)-3a-O- $\beta$-D-xylopyranosyloxymethylbenzofuran and named difengpioside $\mathrm{B}$.

Table 2. NMR data of compounds $2-4$ (in $\mathrm{CD}_{3} \mathrm{OD}, J$ in $\mathrm{Hz}$ ).

\begin{tabular}{|c|c|c|c|c|c|c|}
\hline \multirow{2}{*}{ No. } & \multicolumn{2}{|r|}{2} & \multicolumn{2}{|r|}{3} & \multicolumn{2}{|r|}{4} \\
\hline & $\delta_{C}$ & $\delta_{H}$ & $\delta_{C}$ & $\delta_{H}$ & $\delta_{C}$ & $\delta_{H}$ \\
\hline 1 & 134.7 & & 138.6 & & 133.4 & \\
\hline 2 & 110.6 & $6.97 \mathrm{~d}(1.5)$ & 113.9 & $6.67 \mathrm{~d}(2.0)$ & 113.3 & $6.52 \mathrm{~s}$ \\
\hline 3 & 149.0 & & 148.9 & & 148.9 & \\
\hline 4 & 147.4 & & 145.9 & & 145.6 & \\
\hline 5 & 116.1 & $6.76 \mathrm{~d}(8.0)$ & 116.0 & $6.72 \mathrm{~d}(8.0)$ & 115.9 & $6.65 \mathrm{~d}(8.5)$ \\
\hline 6 & 119.7 & $6.83 \mathrm{dd}(8.0,1.5)$ & 123.2 & $6.59 \mathrm{dd}(8.0,2.0)$ & 122.7 & $6.50 \mathrm{~d}(8.5)$ \\
\hline 7 & 89.0 & $5.44 \mathrm{~d}(6.5)$ & 47.8 & 3.84 br d (11.5) & 36.2 & $2.62 \mathrm{~d}(7.5)$ \\
\hline 8 & 52.7 & $3.57 \mathrm{dd}(13.5,6.5)$ & 48.1 & $1.75 \mathrm{~m}$ & 41.6 & $2.05 \mathrm{~m}$ \\
\hline \multirow[t]{2}{*}{9} & 72.8 & $3.99 \mathrm{dd}(9.5,7.5)$ & 61.6 & $3.35 \mathrm{dd}(11.5,3.0)$ & 69.4 & $3.34 \mathrm{dd}(9.5,5.5)$ \\
\hline & & 3.81 overlap & & $3.68 \mathrm{dd}(11.5,3.0)$ & & $3.80 \mathrm{dd}(9.5,6.5)$ \\
\hline $1^{\prime}$ & 151.6 & & 128.9 & & & \\
\hline $2^{\prime}$ & 96.1 & $6.56 \mathrm{~s}$ & 112.4 & $6.63 \mathrm{~s}$ & & \\
\hline $3^{\prime}$ & 144.9 & & 147.2 & & & \\
\hline $4^{\prime}$ & 155.6 & & 145.2 & & & \\
\hline $5^{\prime}$ & 119.0 & & 117.4 & $6.17 \mathrm{~s}$ & & \\
\hline $6^{\prime}$ & 111.6 & $7.02 \mathrm{~s}$ & 134.1 & & & \\
\hline $7^{\prime}$ & & & 33.7 & 2.81 br d (7.5) & & \\
\hline \multirow[t]{2}{*}{$8^{\prime}$} & & & 37.4 & $2.13 \mathrm{~m}$ & & \\
\hline & & & & $3.63 \mathrm{dd}(10.0,6.0)$ & & \\
\hline $9^{\prime}$ & & & 73.9 & $3.90 \mathrm{dd}(10.0,6.0)$ & & \\
\hline $1^{\prime \prime}$ & 105.0 & $4.31 \mathrm{~d}(7.5)$ & 105.3 & $4.22 \mathrm{~d}(7.5)$ & 102.3 & $4.63 \mathrm{~d}(1.5)$ \\
\hline $2^{\prime \prime}$ & 74.9 & $4.04 \mathrm{dd}(8.5,7.5)$ & 74.9 & $3.19 \mathrm{~m}$ & 72.4 & $3.81 \mathrm{dd}(3.5,1.5)$ \\
\hline $3^{\prime \prime}$ & 77.9 & $3.86 \mathrm{dd}(9.0,4.0)$ & 77.8 & $3.30 \mathrm{~m}$ & 72.6 & $3.67 \mathrm{dd}(9.5,3.5)$ \\
\hline $4^{\prime \prime}$ & 71.2 & $3.50 \mathrm{~m}$ & 71.2 & $3.48 \mathrm{~m}$ & 73.9 & $3.36 \mathrm{t}(9.5)$ \\
\hline \multirow[t]{2}{*}{$5^{\prime \prime}$} & 66.9 & $3.87 \mathrm{dd}(11.0,5.0)$ & 66.9 & $3.20 \mathrm{~m}$ & 70.1 & $3.63 \mathrm{dd}(9.5,6.0)$ \\
\hline & & $3.20 \mathrm{~d}(11.0)$ & & 3.85 br d (11.5) & & \\
\hline $6^{\prime \prime}$ & & & & & 18.0 & $1.25 \mathrm{~d}(6.0)$ \\
\hline 3-MeO & 56.4 & $3.83 \mathrm{~s}$ & 56.3 & $3.77 \mathrm{~s}$ & 56.3 & $3.73 \mathrm{~s}$ \\
\hline $1^{\prime}-\mathrm{MeO}$ & 56.6 & $3.82 \mathrm{~s}$ & & & & \\
\hline $3^{\prime}-\mathrm{MeO}$ & 57.8 & $3.79 \mathrm{~s}$ & 56.4 & $3.79 \mathrm{~s}$ & 56.3 & $3.73 \mathrm{~s}$ \\
\hline
\end{tabular}

Compound 3 was obtained as an amorphous powder with the molecular formula $\mathrm{C}_{25} \mathrm{H}_{32} \mathrm{O}_{10}$, as evidenced by HRESIMS $\left(m / z 515.1920[\mathrm{M}+\mathrm{Na}]^{+}\right.$, calcd. 515.1888). The IR spectrum revealed the presence of hydroxyl $\left(3431 \mathrm{~cm}^{-1}\right)$ and aromatic ring $\left(1631 \mathrm{~cm}^{-1}\right)$ groups. Five typical carbon signals $\left(\delta_{\mathrm{C}} 105.3,77.8,74.9,71.2\right.$, and 66.9$)$ was assigned to a xylose moiety and its $\beta$-orientation was determined by the large coupling constant $(J=7.5 \mathrm{~Hz})$ of the anomeric proton at $\delta_{\mathrm{H}} 4.22$. The ${ }^{13} \mathrm{C}-\mathrm{NMR}$ (Table 2) and HSQC spectra revealed that the remaining signals of 3 contains twelve aromatic carbons of three benzene rings, three methylene carbons including two oxygenated ones at $\delta_{\mathrm{C}} 73.9$ and 61.6, two methoxy carbons at $\delta_{C} 56.4$ and 56.3, three methine carbons at $\delta_{C} 48.1,47.8$ and 37.4. The above data were very similar to those of (+)-isolariciresinol 9-O- $\beta$-D-xylopyranoside (5) [11], except that the difference in the chemical shifts of C-9 and C- $9^{\prime}$. This indicated the xylosyl moiety was positioned at $\mathrm{C}-9^{\prime}$, which was further supported by HMBC correlation observed between $\mathrm{H}-1^{\prime \prime}\left(\delta_{\mathrm{H}} 4.22\right)$ and $\mathrm{C}-9^{\prime}\left(\delta_{\mathrm{C}} 73.9\right)$. The configuration of the xylosyl unit was established as D by HPLC analysis after acid hydrolysis. The absolute configuration of the chiral centers was established to be the same as that of (+)-isolariciresinol from the results of CD spectral analysis [12]. Therefore, compound 3 was elucidated as $(+)$-isolariciresinol- $9^{\prime}-O-\beta$-D-xylopyranoside, with the trivial name difengpioside $C$. It is worth noting that although the literature had been reported a compound with the same name as 3 [13], 
analysis of NMR spectra revealed that the compound actually was identical with (+)-isolariciresinol 9-O- $\beta$-D-xylopyranoside (5).

Compound 4, isolated as an amorphous powder, had the molecular formula $\mathrm{C}_{32} \mathrm{H}_{46} \mathrm{O}_{14}$ deduced from HRESIMS $m / z$ 677.2778 [M + Na] ${ }^{+}$(calcd. for 677.2780). The IR spectrum revealed the presence of hydroxyl $\left(3426 \mathrm{~cm}^{-1}\right)$ and aromatic ring $\left(1631 \mathrm{~cm}^{-1}\right)$ groups. The ${ }^{1} \mathrm{H}-\mathrm{NMR}$ spectrum (Table 2) showed signals of 1,3,4-trisubstituted aromatic ring at $\delta_{\mathrm{H}} 6.65(1 \mathrm{H}, \mathrm{d}, J=8.5 \mathrm{~Hz}), 6.52(1 \mathrm{H}, \mathrm{s})$ and $6.50(1 \mathrm{H}, \mathrm{d}, J=8.5 \mathrm{~Hz})$, a methoxy group at $\delta_{\mathrm{H}} 3.73(3 \mathrm{H}, \mathrm{s})$, and an anomeric proton of rhamnose at $\delta_{\mathrm{H}}$ $4.63(1 \mathrm{H}, \mathrm{d}, J=1.5 \mathrm{~Hz})$ which indicated an $\alpha$-configuration for the sugar moiety. Sixteen carbon signals, including six aromatic carbons, two methylene carbons (including one oxygenated), one methine carbon, one methoxy carbon and six rhamaopyranosyl signals, were supported by the ${ }^{13} \mathrm{C}-\mathrm{NMR}$ (Table 2) and HSQC spectra. The above spectral data combined with the molecular formula indicated 4 possessed a highly symmetrical skeleton. Acid hydrolysis of 4 liberated the L-rhamnose moiety, which was determined by HPLC analysis. The HMBC correlation between $\delta_{\mathrm{H}} 4.63\left(\mathrm{H}-1^{\prime \prime}\right)$ and $\delta_{\mathrm{C}}$ 69.4 (C-9) confirmed that L-rhamnose was linked to C-9. The NMR data of 4 were very similar to those of secoisolariciresinol diglucoside [14], except for the sugar moieties, suggesting that 4 was a diphenylbutane-type lignan dirhamnoside. The symmetrical structure feature of 4 indicated its configuration should be either $8 \mathrm{~S}, 8^{\prime} \mathrm{S}$ or $8 \mathrm{R}, 8^{\prime} \mathrm{R}$. Since two negative Cotton effects at 228 and $280 \mathrm{~nm}$ were observed in the CD spectrum [15], the absolute configuration of 4 was determined to be $8 R, 8^{\prime} R$. Thus, compound 4 was elucidated as (-)-secoisolariciresinol 9,9'-di-O- $\alpha$-L-rhamnopyranoside, which was named as difengpioside $\mathrm{D}$.

The known compounds were identified as (+)-isolariciresinol 9-O- $\beta$-D-xylopyranoside (5) [11], aviculin (6) [16], (+)-isolariciresinol (7) [12], (-)-secoisolariciresinol-O- $\alpha$-L-rhamnopyranoside (8) [17], 7S,8R-threo-3', 9, 9' -trihydroxy-3-methoxy-4',7-epoxyneolignan-4-O- $\alpha$-L-rhamnopyranoside (9) [5], icariside E4 (10) [5], threo-4,9, $9^{\prime}$-trihydroxy-3,3'-dimethoxy-8-O-4'-neolignan 7-O- $\alpha$-rhamno-pyranoside (11) [18], respectively, by comparison of the spectroscopic data with those reported in the literature.

Inhibitors of NO release are considered as potential anti-inflammatory agents [19]. Since the stem barks of Illicium difengpi have been applied for the treatment of rheumatic arthritis in China, the isolated compounds were evaluated for their effects on the inhibition of NO production in LPS-activated RAW264.7 cells. As shown in Table 3, the dihydrobenzofuran-type (1, 2, 9, and 10) and aryltetralin-type $(3,5,6$, and 7) lignan glycosides exhibited weak inhibitory effect against $\mathrm{NO}$ with inhibition ratios in the range of $3.29 \%$ to $10.53 \%$ at a concentration of $25 \mu \mathrm{M}$, while the dibenzylbutane-type lignan glycosides $\mathbf{4}$ and $\mathbf{8}$ and neolignan glucoside $\mathbf{1 1}$ showed no inhibitory effect at the same concentration.

Table 3. Inhibitory effects of compounds 1-11 on NO production.

\begin{tabular}{ccc}
\hline Compound & Conc. $(\boldsymbol{\mu M})$ & Inhibitory Rate $\mathbf{( \% )}$ \\
\hline $\mathbf{1}$ & 25 & 7.24 \\
$\mathbf{2}$ & 25 & 5.69 \\
$\mathbf{3}$ & 25 & 4.61 \\
$\mathbf{4}$ & 25 & -0.65 \\
$\mathbf{5}$ & 25 & 10.53 \\
$\mathbf{6}$ & 25 & 3.95 \\
$\mathbf{7}$ & 25 & 3.29 \\
$\mathbf{8}$ & 25 & 1.32 \\
$\mathbf{9}$ & 25 & 3.30 \\
$\mathbf{1 0}$ & 25 & 4.05 \\
$\mathbf{1 1}$ & 25 & 0.66 \\
MG132 & 0.125 & 91.19 \\
\hline
\end{tabular}

a Positive control, carbobenzoxy-leu-leu-leucinal. 


\section{Materials and Methods}

\subsection{General Information}

Melting points were obtained on an X-4 micro melting point apparatus (Shanghai Jingke Scientific Instrument Co., Ltd, Shanghai, China). Optical rotations were measured with a P-1020 polarimeter (JASCO, Tokyo, Japan). UV spectra were obtained on a UV-2401A spectrophotometer (Shimadzu, Kyoto, Japan). CD spectra were recorded on a J-810 CD spectrometer (JASCO, Tokyo, Japan). IR spectra were measured in a FTS-135 spectrometer (Bio-Rad, Richmond, CA, USA) with KBr pellets. HRESIMS were recorded on a LCMS-IT-TOF spectrometer (Shimadzu, Kyoto, Japan). The NMR spectra were recorded on a DRX-500 spectrometer (Bruker Co., Ettlingen, Germany) with TMS as internal standard, and chemical shifts $(\delta)$ were expressed in ppm with reference to the solvent signals. Silica gel (200-300 mesh; Qingdao Marine Chemical Inc., Qingdao, China), D101 macroporous resin

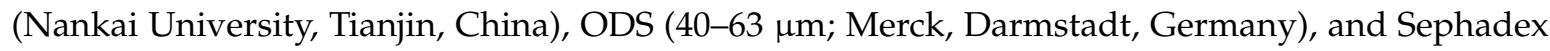
LH-20 (Amersham Pharmacia Biotech, Uppsala, Sweden) were used for column chromatography. Semipreparative HPLC was performed on an Agilent 1200 apparatus equipped with a UV detector and a Zorbax SB-C-18 (9.4 mm $\times 25 \mathrm{~cm}$, Agilent Technologies, Santa Clara, CA, USA) column. Analytical HPLC was performed on a Shimadzu HPLC system equipped with a refractive index detector and a CARBOSep COREGEL-87C Ca ${ }^{+}(7.8 \times 300$ mm, $9 \mu \mathrm{m}$, Transgenomic Inc., Omaha, NE, USA) column. Fractions were monitored by TLC and spots were visualized by heating silica gel plates sprayed with $10 \% \mathrm{H}_{2} \mathrm{SO}_{4}$ in $\mathrm{EtOH}$. Solvents were distilled before use.

\subsection{Plant Material}

The stem barks of Illicium difengpi were collected from Longzhou County, Guangxi Province, China, in October 2010 and identified by Prof. H. Tang. A voucher specimen (CTM201002) was deposited at the Guangxi Key Laboratory of Functional Phytochemicals Research and Utilization, Guangxi Institute of Botany, China.

\subsection{Extraction and Isolation}

The air-dried stem barks of I. difengpi $(14 \mathrm{~kg})$ were extracted with $95 \% \mathrm{EtOH}(20 \mathrm{~L} \times 3)$ at room temperature for $24 \mathrm{~h}$. The dried EtOH extract $\left(1.3 \mathrm{~kg}\right.$ ) was suspended in $\mathrm{H}_{2} \mathrm{O}$ and then partitioned successively with petroleum ether $(1.5 \mathrm{~L} \times 3)$, EtOAc $(1.5 \mathrm{~L} \times 3)$ and $n$-BuOH $(1.5 \mathrm{~L} \times 3)$. The $n$-butanol portion (540 g) was applied to a D101 macroporous resin column eluted with water, 10\%, 30\%, 60\%, $90 \%$ and $100 \%$ methanol. The 30\% methanol fraction (32 g) was further purified by an ODS column and a preparative $\mathrm{HPLC}\left(\mathrm{CH}_{3} \mathrm{CN}-\mathrm{H}_{2} \mathrm{O}, 15: 85\right)$ to yield compounds 1 (9 $\left.\mathrm{mg}\right)$ and $4(12 \mathrm{mg})$. The $60 \%$ methanol fraction (26 g) was subjected to a Sephadex LH-20 column eluted with MeOH to give five fractions (Fr. 1-5). Fr.3 was further separated by an ODS column and preparative $\mathrm{HPLC}\left(\mathrm{CH}_{3} \mathrm{CN}-\mathrm{H}_{2} \mathrm{O}\right.$, 15:85 to 30:70) to obtain compounds $\mathbf{8}(25 \mathrm{mg}), \mathbf{1 0}(30 \mathrm{mg})$ and $\mathbf{1 1}(8 \mathrm{mg})$. Fr.4 was subjected to silica gel column chromatography $\left(\mathrm{CHCl}_{3}-\mathrm{MeOH}-\mathrm{H}_{2} \mathrm{O}, 5: 1: 0.1\right.$ to 3:1:0.1) and preparative $\mathrm{HPLC}\left(\mathrm{CH}_{3} \mathrm{CN}-\mathrm{H}_{2} \mathrm{O}\right.$, 15:85 to 30:70) to obtain compounds 2 (6 mg), 3 (10 mg), 5 (35 mg), 6 (33 mg) and 9 (40 mg). The 90\% methanol fraction (12 g) was further purified by silica gel column chromatography $\left(\mathrm{CHCl}_{3}-\mathrm{MeOH}_{\text {, }}\right.$ 5:1 to $0: 1)$ and preparative $\mathrm{HPLC}\left(\mathrm{CH}_{3} \mathrm{CN}-\mathrm{H}_{2} \mathrm{O}, 30: 70\right)$ to yield compound 7 (10 mg).

\subsection{Compound Characterization}

Difengpioside A (1): Amorphous powder; $[\alpha]_{\mathrm{D}}^{20}+25$ (c 0.2, MeOH); IR (KBr) $v_{\max }: 3406,2933$, 1609, 1511, 1267, $1030 \mathrm{~cm}^{-1}$; UV (MeOH) $\lambda \max (\log \varepsilon) \mathrm{nm}: 204$ (4.47), 281 (3.55); CD (MeOH, nm) $\lambda_{\max }$ $(\Delta \varepsilon) 290$ (-3.18), 254 (-2.55), $237(-3.27) ;{ }^{1} \mathrm{H}$ and ${ }^{13} \mathrm{C}-\mathrm{NMR}$ data, see Table 1 ; HRESIMS $m / z 707.2581$ $[\mathrm{M}+\mathrm{Na}]^{+}$(calcd for $\mathrm{C}_{36} \mathrm{H}_{44} \mathrm{O}_{13} \mathrm{Na}$, 707.2674).

Difengpioside B (2): white amorphous powder; $[\alpha]_{\mathrm{D}}^{20}+21(c$ 0.2, $\mathrm{MeOH})$; IR (KBr) $v_{\max }: 3412,2937$, 1595, 1501, 1461, 1124, $1034 \mathrm{~cm}^{-1}$; UV (MeOH) $\lambda \max (\log \varepsilon) \mathrm{nm}: 206$ (4.87), 281 (3.58); CD (MeOH, 
nm) $\lambda_{\max }(\Delta \varepsilon) 287(-3.57), 254(-3.39), 243(-4.10), 213(-2.90) ;{ }^{1} \mathrm{H}$ and ${ }^{13} \mathrm{C}-\mathrm{NMR}$ data, see Table 2; HRESIMS $m / z 487.1572[\mathrm{M}+\mathrm{Na}]^{+}$(calcd for $\mathrm{C}_{23} \mathrm{H}_{28} \mathrm{O}_{10} \mathrm{Na}$, 487.1575).

Difengpioside C (3): white amorphous powder; $[\alpha]_{\mathrm{D}}^{20}+16(c 0.2, \mathrm{MeOH}) ; \mathrm{IR}(\mathrm{KBr}) \gamma_{\max }$ : 3431, 2924, 1631, 1384, $1049 \mathrm{~cm}^{-1}$; UV (MeOH) $\lambda_{\max }(\log \varepsilon) \mathrm{nm}: 204$ (3.45), 281 (2.59); CD (MeOH, nm) $\lambda_{\max }$ $(\Delta \varepsilon) 292(-0.21), 277(0.16), 239(0.20), 213(0.56) ;{ }^{1} \mathrm{H}$ and ${ }^{13} \mathrm{C}-\mathrm{NMR}$ data, see Table 2; HRESIMS $\mathrm{m} / \mathrm{z}$ $515.1967[\mathrm{M}+\mathrm{Na}]^{+}$(calcd for $\mathrm{C}_{25} \mathrm{H}_{32} \mathrm{O}_{10} \mathrm{Na}, 515.1888$ ).

Difengpioside D (4): white amorphous powder; $[\alpha]_{\mathrm{D}}^{20}-32(c 0.2, \mathrm{MeOH}) ; \mathrm{IR}(\mathrm{KBr}) v_{\max }: 3426$, 2932, 1631, $1141 \mathrm{~cm}^{-1}$; UV (MeOH) $\lambda_{\max }(\log \varepsilon) \mathrm{nm}: 204$ (4.68), 281 (3.64); CD (MeOH, nm) $\lambda_{\max }(\Delta \varepsilon)$ 280 (-0.89), $228(-1.98), 211(-5.35) ;{ }^{1} \mathrm{H}$ - and ${ }^{13} \mathrm{C}-\mathrm{NMR}$ data, see Table 2; HRESIMS $m / z$ 677.2778 $[\mathrm{M}+\mathrm{Na}]^{+}$(calcd for $\left.\mathrm{C}_{32} \mathrm{H}_{46} \mathrm{O}_{14} \mathrm{Na}, 677.2780\right)$.

\subsection{Determination of the Absolute Configuration of the Sugars in Compounds 1-4}

Each compound $(1.5 \mathrm{mg})$ was dissolved in $0.5 \mathrm{M} \mathrm{HCl}(0.2 \mathrm{~mL})$ and heated at $80{ }^{\circ} \mathrm{C}$ for $2 \mathrm{~h}$. The mixture was desalinated by passing through columns of anion and cation exchange resin and then filtered. The filtrate was directly analyzed by a Shimadzu HPLC system equipped with a refractive index detector and a CARBOSep COREGEL-87C Ca ${ }^{+}$column $(7.8 \times 300 \mathrm{~mm}, 9 \mu \mathrm{m}$, Transgenomic Inc.) at $85{ }^{\circ} \mathrm{C}$ with elution of HPLC grade water for $18 \mathrm{~min}$ at a flow rate of $0.5 \mathrm{~mL} / \mathrm{min}$. The injection volume was $20 \mu \mathrm{L}$. The standards L-rhamnose and D-xylose were treated by the same water and chromatographic conditions. The sugars from each compound were identified by comparison of their retention times with those for authentic standards $\left(t_{\mathrm{R}}: 13.67 \mathrm{~min}\right.$ for L-rhamnose, $13.13 \mathrm{~min}$ for D-xylose).

\subsection{NO Production Inhibition Assay}

Assays for NO production were carried out as previously described [20]. Briefly, RAW 264.7 macrophages were harvested and seeded in 96-well plates $\left(3 \times 10^{4}\right.$ cells /well) for measurement of NO production. The plates were pretreated with various samples for $30 \mathrm{~min}$ and then incubated with $1 \mu \mathrm{g} / \mathrm{mL}$ LPS for $24 \mathrm{~h}$. The inhibitory effects of the isolated compounds on NO production were evaluated by using the Griess reagent.

\section{Conclusions}

Eleven compounds, including four new lignan glucosides 1-4, named difengpiosides A-D, were isolated from the $n-\mathrm{BuOH}$-soluble fraction of an $\mathrm{EtOH}$ extract of the stem barks of I. difengpi. All compounds showed weak or no inhibitory activities against NO production at the concentration of $25 \mu \mathrm{M}$, indicating that the polar constituents of this plant showed no inflammatory activity in vitro.

Supplementary Materials: Supplementary materials can be accessed at: http://www.mdpi.com/1420-3049/21/ 5/607/s1. HRESIMS, 1D- and 2D-NMR, IR, and CD spectra of four new compounds 1-4.

Acknowledgments: This work was supported by the Guangxi Scientific Research and Technology Development Program (14125008-2-23), the Science Research Foundation of Guangxi Institute of Botany (13015), the Foundation of Guangxi Key Laboratory of Functional Phytochemicals Research and Utilization (ZRJJ2014-2), and the Bagui Scholar Program of Guangxi.

Author Contributions: Zheng-Hong Pan and Dian-Peng Li organized and designed the experiments; Zheng-Hong Pan wrote the manuscript; De-Sheng Ning, Si-Si Huang, Ling Cheng, and Meng-Wen Xia performed the experiments; De-Sheng Ning conducted NMR measurement and analyzed the data; Li-Yan Peng helped to evaluate the bioactivities.

Conflicts of Interest: The authors declare no conflict of interest.

\section{References}

1. Editorial Committee of Chinese Pharmacopoeia. Chinese Pharmacopoeia, 2015 ed.; China Medical Science Press: Beijing, China, 2015; p. 123. 
2. Huang, P.; Xi, Z.M.; Zheng, X.Z.; Lai, M.X.; Zhong, X.Q. Studies on the chemical constituents of the Traditional Chinese Medicine “DIFENGPI". Acta Pharm. Sin. 1996, 31, 278-281.

3. Huang, P.; Xi, Z.M.; Zheng, X.Z.; Lai, M.X.; Zhong, X.Q. Triterpene acids from the barks of Illicium difengpi. Acta Pharm. Sin. 1997, 32, 704-707.

4. Kouno, I.; Yanagida, Y.; Shimono, S.; Shintomi, M.; Yang, C.S. Phenylpropanoids from the barks of Illicium difengpi. Chem. Pharm. Bull. 1992, 40, 2461-2464. [CrossRef]

5. Kouno, I.; Yanagida, Y.; Shimono, S.; Shintomi, M.; Ito, Y.; Yang, C.S. Neolignans and a phenylpropanoid glucoside from Illicium difengpi. Phytochemistry 1993, 32, 1573-1577. [CrossRef]

6. Fang, L.; Du, D.; Ding, G.Z.; Si, Y.K.; Yu, S.S.; Liu, Y.; Wang, W.J.; Ma, S.G.; Xu, S.; Qu, J.; et al. Neolignans and glycosides from the stem barks of Illicium difengpi. J. Nat. Prod. 2010, 73, 818-824. [CrossRef] [PubMed]

7. Fang, L.; Wang, X.J.; Ma, S.G.; Yu, S.S. A new sesquiterpene lactone and a new aromatic glycoside from Illicium difengpi. Acta Pharm. Sin. B 2011, 1, 178-183. [CrossRef]

8. Gu, Q.; Zhang, X.M.; Zhou, J.; Qiu, S.X.; Chen, J.J. One new dihydrobenzofuran lignan from Vitex trifolia. J. Asian Nat. Prod. Res. 2008, 10, 499-502. [CrossRef] [PubMed]

9. Li, S.; Iliefski, T.; Lundquist, K.; Wallis, A.F.A. Reassignment of relative stereochemistry at C-7 and C-8 in arylcoumaran neolignans. Phytochemistry 1997, 46, 929-934. [CrossRef]

10. Kim, T.H.; Ito, H.; Hayashi, K.; Hasegawa, T.; Machiguchi, T.; Yoshida, T. Aromatic constituents from the heartwood of Santalum album L. Chem. Pharm. Bull. 2005, 53, 641-644. [CrossRef] [PubMed]

11. Zhang, J.J.; Ma, Y.P.; Yuan, J.Z.; Sun, Q.S. Isolation and identification of lignans from pine needles of Pinus koraiensis Sieb. et Zucc. J. Shenyang Pharm. Univ. 2010, 27, 797-802.

12. Baderschneider, M.; Winterhalter, P. Isolation and characterization of novel benzoates, cinnamates, flavonoids, and lignans from Riesling wine and screening for antioxidant activity. J. Agric. Food Chem. 2001, 49, 2788-2798. [CrossRef] [PubMed]

13. Bu, P.B.; Li, Y.R.; Jiang, M.; Wang, X.L.; Wang, F.; Lin, S.; Zhu, C.G.; Shi, J.G. Lignans from Machilus robusta. Chin. J. Chin. Mater. Med. 2013, 38, 1740-1746.

14. Qiu, S.X.; Lu, Z.Z.; Luyengi, L.; Lee, S.K.; Pezzuto, J.M.; Farnsworth, N.R.; Thompson, L.U.; Fong, H.H.S. Isolation and characterization of Flaxseed (Linum usitatissimum) constituents. Pharm. Biol. 1999, 37, 1-7. [CrossRef]

15. Xie, L.H.; Akao, T.; Hamasaki, K.; Deyama, T.; Hattori, M. Biotransformation of pinoresinol diglucoside to mammalian lignans by human intestinal microflora, and isolation of enterococcus faecalis strain PDG-1 responsible for the transformation of (1)-pinoresinol to (1)-lariciresinol. Chem. Pharm. Bull. 2003, 51, 508-515. [CrossRef] [PubMed]

16. Liu, J.F.; Zhang, X.M.; Shi, Y.; Jiang, Z.Y.; Ma, Y.B.; Chen, J.J. Chemical constituents from rhizomes of Illicium henryi. Chin. J. Chin. Mater. Med. 2010, 35, 2281-2284.

17. Chen, X.C.; Jia, Z.J. Two new glycosides from Rubus amabilis. Chinese Chem. Lett. 2000, 11, 897-900.

18. Liu, J.F.; Jiang, Z.Y.; Geng, C.A.; Zhang, Q.; Shi, Y.; Ma, Y.B.; Zhang, X.M.; Chen, J.J. Two new lignans and anti-HBV constituents from Illicium henryi. Chem. Biodivers. 2011, 8, 692-698. [CrossRef] [PubMed]

19. Kerwin, J.F., Jr.; Lancaster, J.R., Jr.; Feldman, P.L. Nitric oxide: A new paradigm for second messengers. J. Med. Chem. 1995, 38, 4343-4362. [CrossRef] [PubMed]

20. Zhang, L.; Dong, L.; Huang, J.; Liu, M.S.; Li, G.Y.; Zhang, C.; Zhang, K.; Wang, J.H. 3, 4-seco-Labdane diterpenoids from the leaves of Callicarpa nudiflora and their inhibitory effects on nitric oxide production. Fitoterapia 2013, 89, 218-223. [CrossRef] [PubMed]

Sample Availability: Samples of the compounds 1-11 are not available from the authors.

(C) 2016 by the authors; licensee MDPI, Basel, Switzerland. This article is an open access article distributed under the terms and conditions of the Creative Commons Attribution (CC-BY) license (http:/ / creativecommons.org/licenses/by/4.0/). 